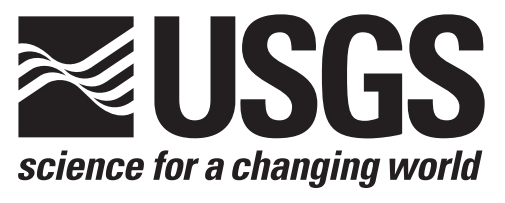

\title{
Preliminary Spreadsheet of Eruption Source Parameters for Volcanoes of the World
}

By Larry G. Mastin, Marianne Guffanti, John W. Ewert, and Jessica Spiegel

Version 1.2

Open-File Report 2009-1133

U.S. Department of the Interior

U.S. Geological Survey 


\title{
U.S. Department of the Interior KEN SALAZAR, Secretary
}

\section{U.S. Geological Survey Suzette M. Kimball, Acting Director}

U.S. Geological Survey, Reston, Virginia: 2009

\author{
For product and ordering information \\ :World Wide Web: http://www.usgs.gov/pubprod \\ Telephone: 1-888-ASK-USGS \\ For more information on the USGS--the Federal source for science about the Earth, its natural and living \\ resources, natural hazards, and the environment: \\ World Wide Web: http://www.usgs.gov \\ Telephone: 1-888-ASK-USGS \\ Any use of trade, product, or firm names is for descriptive purposes only and does not imply endorsement by \\ the U.S. Government.
}

Suggested reference:

Mastin, L.G., Guffanti, M., Ewert, J.E., and Spiegel, J., 2009, Preliminary spreadsheet of eruption source parameters for volcanoes of the world: U.S. Geological Survey Open-File Report 2009-1133, v. 1.2, 25 p.

Available at $h$ ttp://pubs.usgs.gov/of/2009/1133/ 


\section{Introduction}

Volcanic eruptions that spew tephra into the atmosphere pose a hazard to jet aircraft. For this reason, the International Civil Aviation Organization (ICAO) has designated nine Volcanic Ash and Aviation Centers (VAACs) around the world whose purpose is to track ash clouds from eruptions and notify aircraft so that they may avoid these ash clouds. During eruptions, VAACs and their collaborators run volcanic-ashtransport-and-dispersion (VATD) models that forecast the location and movement of ash clouds. These models require as input parameters the plume height $H$, the mass-eruption rate $\dot{M}$, duration $D$, erupted volume $V$ (in cubic kilometers of bubble-free or "dense rock equivalent" [DRE] magma), and the mass fraction of erupted tephra with a particle size smaller than $63 \mu \mathrm{m}\left(m_{63}\right)$. Some parameters, such as mass-eruption rate and mass fraction of fine debris, are not obtainable by direct observation; others, such as plume height or duration, are obtainable from observations but may be unavailable in the early hours of an eruption when VATD models are being initiated. For this reason, ash-cloud modelers need to have at their disposal source parameters for a particular volcano that are based on its recent eruptive history and represent the most likely anticipated eruption. They also need source parameters that encompass the range of uncertainty in eruption size or characteristics.

In spring of 2007, a workshop was held at the U.S. Geological Survey (USGS) Cascades Volcano Observatory to derive a protocol for assigning eruption source parameters to ash-cloud models during eruptions. The protocol derived from this effort was published by Mastin and others (in press), along with a world map displaying the assigned eruption type for each of the world's volcanoes. Their report, however, did not include the assigned eruption types in tabular form. Therefore, this Open-File Report presents that table in the form of an Excel spreadsheet. These assignments are preliminary and will be modified to follow upcoming recommendations by the volcanological and aviation communities.

\section{Assigned Eruption types and Source Parameters}

To assign eruption source parameters to the world's volcanoes, we collected published data from well-documented eruptions and used those data to derive 11 types of volcanic eruptions, as listed in table 1. Associated with each eruption type are values of the eruption source parameters - plume height, eruption rate, erupted volume, duration, and mass fraction of fine tephra. We then assigned one of these eruption types to each of the world's volcanoes, as described below. 
Table 1. Guidelines used to assign eruption types to the world's volcanoes.

[The symbol $H$ indicates characteristic plume height of recent historical eruptions. We assume that the most likely future eruption will resemble past recent eruptions. If both plume height and volcanic explosivity index (VEI) are available, the plume height that characterizes most eruptions at this volcano in recent decades is used to assign an eruption type. Otherwise, the VEI that characterizes most of the recent eruptions is used to assign an eruption type. Eruption type S8 (elutriated ash column) is assigned to a volcano only during an eruption on the basis of whether large-scale pyroclastic flows are being produced, not on the basis of historical activity.]

\begin{tabular}{|c|c|c|}
\hline Type & Magma type & $\begin{array}{c}\text { Historical eruption } \\
\text { characteristics }\end{array}$ \\
\hline M0 & \multirow[t]{4}{*}{$\begin{array}{l}\text { Basalt or other } \\
\text { mafic }\end{array}$} & $\begin{array}{l}\text { Insufficient historical } \\
\text { data to characterize }\end{array}$ \\
\hline M1 & & $H \leq 5 \mathrm{~km}$ or $\mathrm{VEI} \leq 2$ \\
\hline M2 & & $H=5-8 \mathrm{~km}$ or $\mathrm{VEI}=3$ \\
\hline M3 & & $>8 \mathrm{~km}$ or $\mathrm{VEI} \geq 4$ \\
\hline S0 & \multirow{6}{*}{$\begin{array}{l}\text { Andesite, dacite, } \\
\text { rhyolite, or other } \\
\text { explosive } \\
\text { composition }\end{array}$} & $\begin{array}{l}\text { Insufficient historical } \\
\text { data to characterize }\end{array}$ \\
\hline S1 & & $H \leq 6 \mathrm{~km}$ or $\mathrm{VEI} \leq 2$ \\
\hline $\mathrm{S} 2$ & & $H=6-12 \mathrm{~km}$ or $\mathrm{VEI}=3$ \\
\hline S3 & & $H \geq 12 \mathrm{~km}$ or $\mathrm{VEI} \geq 4$ \\
\hline S8 & & $\begin{array}{l}\text { Major pyroclastic flows, } \\
\text { with an elutriated column } \\
\text { rising primarily above } \\
\text { the flows. }\end{array}$ \\
\hline S9 & & $\begin{array}{l}\text { Active lava dome is } \\
\text { present }\end{array}$ \\
\hline U0 & All magma types & $\begin{array}{l}\text { Submarine vent with a } \\
\text { water depth } \geq 50 \mathrm{~m}\end{array}$ \\
\hline
\end{tabular}

The assigned eruption type for each volcano is based on its historical behavior (or lack thereof), using the guidelines summarized in Mastin and others (in press) and recapitulated here and in table 2. At volcanoes where the magma type of recent eruptions is known, we assign an eruption type "M" (mafic; for example, basalt or similar lowviscosity magma) or " $\mathrm{S}$ " ( silicic; for example, andesite, dacite, rhyolite, or other higherviscosity magma). For a given eruption size as measured by plume height or erupted volume, mafic and silicic eruptions typically display somewhat different durations and grain-size distributions and so are assigned slightly different source parameters in the classification scheme. If the magma type is unknown or inaccessible, we assign it on the basis of the type of volcanic feature in the Smithsonian Institution database (Siebert and Simkin, 2002-9). For example, shield volcanoes, fissure vents, cinder cones, and maars are considered mafic; whereas stratovolcanoes, lava domes, pumice cones, calderas, complex volcanoes, explosion craters, and bimodal volcanic fields are considered silicic. For volcanoes with enough well-described historical eruptions to discern a trend, we assign future eruption type based on plume height of observed eruptions (where available) or on the characteristic eruption size as listed in the Smithsonian Institution database, using the volcanic explosivity index (VEI) of Newhall and Self (1982). For volcanoes that erupted many times in the past century, we give particular weight to eruptions in the past few decades in assigning an eruption type. Volcanoes with no welldescribed historical activity are assigned default type M0 or S0, and volcanoes whose vents lie more than $50 \mathrm{~m}$ below the ocean surface are assigned type U0, which is assumed to produce no eruptive plume. 
Table 2. Eruption types and source parameters assigned to each eruption type

[The mass eruption rate, $\dot{M}$, erupted volume $V$, and mass fraction of fine ash $m_{63}$ for each eruption type are based on mapping and characterization of the tephra-fall deposits at the example eruptions given in column 2. Plume height $H$ and eruption duration $D$ are from historical accounts. Types $\mathrm{M} 1, \mathrm{M} 2, \mathrm{M} 3, \mathrm{~S} 1, \mathrm{~S} 2, \mathrm{~S} 3, \mathrm{~S} 8, \mathrm{~S} 9$, and $\mathrm{U} 0$ are assigned to each eruption. Type "M", or mafic types, include basaltic and ultramafic magmas; type "S", or silicic types, include andesite, dacite, rhyolite, and others, such as phonolite, that can produce high ash columns. Submarine eruptions that occur beneath at least 50-m water depth are assigned type "U0".]

\begin{tabular}{|l|l|c|c|c|c|c|}
\hline \multicolumn{1}{|c|}{ Eruption type } & \multicolumn{1}{|c|}{$\begin{array}{c}\text { Example } \\
\text { (Date as M/D/Y) }\end{array}$} & $\begin{array}{c}\mathbf{H}, \mathbf{k m} \\
\text { above } \\
\text { vent }\end{array}$ & $\begin{array}{c}\mathbf{D} \\
\mathbf{h r}\end{array}$ & $\begin{array}{c}\dot{M} \\
\mathbf{k g} / \mathbf{s}\end{array}$ & $\begin{array}{c}\boldsymbol{V} \\
\mathbf{k m}^{3}\end{array}$ & $\mathbf{m}_{63}$ \\
\hline Mafic, standard (M0) & Cerro Negro, Nicaragua, 4/9-13/1992 & 7 & 60 & $1 \times 10^{5}$ & 0.01 & 0.05 \\
\hline Small (M1) & Mount Etna, Italy, 7/19-24/2001 & 2 & 100 & $5 \times 10^{3}$ & 0.001 & 0.02 \\
\hline Medium (M2) & Cerro Negro, Nicaragua, 4/9-13/1992 & 7 & 60 & $1 \times 10^{5}$ & 0.01 & 0.05 \\
\hline Large (M3) & Fuego, Guatemala, 10/14/1974 & 10 & 5 & $1 \times 10^{6}$ & 0.17 & 0.1 \\
\hline Silicic, standard (S0) & Mount Spurr, USA, 8/18/1992 & 11 & 3 & $4 \times 10^{6}$ & 0.015 & 0.4 \\
\hline Small (S1) & $\begin{array}{l}\text { Mount Ruapehu, New Zealand, } \\
\text { 6/17/1996 }\end{array}$ & 5 & 12 & $2 \times 10^{5}$ & 0.003 & 0.1 \\
\hline Medium (S2) & Mount Spurr, USA, 8/18/1992 & 11 & 3 & $4 \times 10^{6}$ & 0.015 & 0.4 \\
\hline Large (S3) & Mount St. Helens, USA, 5/18/1980 & 15 & 8 & $1 \times 10^{7}$ & 0.15 & 0.5 \\
\hline $\begin{array}{c}\text { Co-ignimbrite } \\
\text { cloud (S8) }\end{array}$ & $\begin{array}{c}\text { Mount St. Helens, USA, 5/18/1980 } \\
\text { (pre-9 AM) }\end{array}$ & 25 & 0.5 & $1 \times 10^{8}$ & 0.05 & 0.5 \\
\hline $\begin{array}{c}\text { Brief (S9) } \\
\text { Soufrière Hills, Montserrat } \\
\text { (composite) }\end{array}$ & 10 & 0.01 & $3 \times 10^{6}$ & 0.0003 & 0.6 \\
\hline Submarine (U0) & None & 0 & -- & -- & -- & \\
\hline
\end{tabular}

\section{Format of the Spreadsheet}

Columns A through $\mathrm{O}$ in table 3 are the original columns in the Smithsonian Institution database. (To save space in the PDF version, columns B through $\mathrm{G}$, J, and $\mathrm{O}$ are omitted). Column $\mathrm{P}$ is the eruption type, which uses the labels M0, M1, S0, etc. defined in table 1. Volcanoes with historical activity are highlighted in gray.

\section{Uncertainty in Assigned Eruption Source Parameters}

These assignments represent our best assessment of the type and size of future eruptions, but actual eruptions will vary from these predictions. To account for the possible range of values, modelers should consider running multiple scenarios, such as the following:

1. Run forecasts for eruption types M1, M2, and M3 or for eruption types S1, S2, and S3 simultaneously, depending on the volcano's magma type.

2. For type S9 volcanoes, run models S1, S2, S3, and S9.

3. For type U0 volcanoes, run models for eruption types M1 and M2.

As observations are acquired during an eruption, some scenarios can be eliminated, and others refined. 


\section{Future Revisions}

The assigned eruption source parameters listed in column $\mathrm{P}$ of table 3 are preliminary. Assignments will change as we obtain input from colleagues with expertise in each geographic region, and as volcanic activity unfolds. The version number at the time of writing is given on the title page. The eruption types listed in table 1 may also be modified to incorporate more realistic or robust models, or to consider uncertainty. A workshop at the U.S. Geological Survey's Cascades Volcano Observatory in September 2009 will identify possible improvements to this scheme. Major changes, if they are undertaken, would be described in a new document and spreadsheet by the Eruption Source Parameters Workgroup (headed by the authors of this report). Changes in the assigned eruption type of individual volcanoes would also be made by the workgroup, in consultation with experts on that volcano.

\section{References Cited}

Mastin, L.G., Guffanti, M., Servranckx, R., Webley, P., Barsotti, S., Dean, K., Denlinger, R., Durant, A., Ewert, J.W., Neri, A., Rose, W.I., Schneider, D., Siebert, L., Stunder, B., Swanson, G., Tupper, A., Volentik, A., and Waythomas, C.F., in press, A multidisciplinary effort to assign realistic source parameters to models of volcanic ash-cloud transport and dispersion during eruptions: Journal of Volcanology and Geothermal Research.

Newhall, C.G., and Self, S., 1982, The volcanic explosivity index (VEI): an estimate of explosive magnitude for historical volcanism: Journal of Geophysical Research, v. 87, p. 1231-1238.

Siebert, L., and Simkin, T., 2002-9, Volcanoes of the World: an Illustrated Catalog of Holocene Volcanoes and their Eruptions, Smithsonian Institution, Global Volcanism Program Digital Information Series, GVP-3 [http://www.volcano.si.edu/world/summary.xls]. 